\title{
2015 年日本第四紀学会賞受賞記念論文
}

\section{生業動態からみた縄文時代人の食料戦略 — sustainable use の先駆者としての縄文文化一}

\author{
小池裕 子*
}

\begin{abstract}
本論は縄文時代の食料戦略から考えた生業動態論を紹介したものである.まず筆者が院生時代 に没頭した貝殼成長線解析を用いた貝殼構造や貝殼形成機構の研究, 数々の貝塚遺跡や住居址内 貝層から出土した貝殼を収集して行った季節推定や貝類資源の位置づけ，および海況環境復元か ら始まったパレオバイオマス (Paleobiomass) 分析を紹介した。 また貝類以外の動物資源の季節 推定を進める中で, ヒトと食料資源の関係を考える生業動態 (Exploitation dynamics) や捕獲圧 (Hunting-collecting pressure) 分析へと展開し, 縄文時代人の持続可能な生業のあり方 (sustainable use）について推論を紹介した。 その根底にあるものは, 多様な食料資源を適切に選択しながら 利用することで, 対象動植物の生態のみならず, シカ捕獲の上限など資源管理の知識ももち合わ せていたと考えられる. 一方, 縄文時代の増加期型集落と飽和期型集落などの社会構造について は, 今後古人骨の aDNA など新技術の適用によって, 集落内・集落間の移動や拡散, 社会的階 層化・儀礼行為の発達などとの関連性が解明されることを期待したい.
\end{abstract}

キーワード : 貝殼成長線解析, 哺乳動物の歯牙年輪, パレオバイオマス分析, 生業動態分析, 捕 獲圧，生業日誌

\section{I. は じめに}

2015 年度の日本第四紀学会賞として, 「貝喨成長線, 安 定同位体, 脂肪酸, mtDNA などを用いた先史生態学に 関する一連の研究」ということで受賞させていただき, 身 に余る光栄なことと大変恐縮しております，そこで，著 者自身最近の研究の進展はあまりありませんが, 多少と も学会に貢献すればと思い筆を取らせていただきます。

関東地方には 600 力所を超える貝塚遺跡が知られて いる．住居址内貝層も合わせるともっと多いだろう，貝 塚遺跡は首都圈の開発によって消失したものも多いが, 1980 年代の開発期でさえ, 貝塚遺跡の保存を計画に盛 り达んだ地域開発整理事業が実施され貴重な大貝塚が保 存されてきた．まだまだ多数の貝塚遺跡は残され，また 後世に引き継がれなくてはならないが，これらの貴重な 文化遺産から現代人が学ばなければならないことは多 い.

日本の経済の高度成長期にあたる 1980 年代は, 行政
が財政的にも人材的にも主体となって発掘調查が推進さ れた. ニュータウン計画など丘陵地帯にも開発の波が訪 れ, 千葉県船橋市の海老作貝塚, 千葉県千葉市の木戸 作貝塚や千葉県市原市の西広貝塚など多くの貝塚遺跡が 全面発掘され, 考古学的には大きな研究成果が得られ た.このように遺跡か整然と全面発掘され，精力的に整 理報告書が作成された．著者の貝類研究もこのような大 規模発掘によって貴重な資料が得られ進展してきた.

このような大規模開発には，環境アセスなども体系的 に行われ，沖積層を用いた環境復元も大いに進展した. より広域で詳細な環境復元が提示され, 遺跡周辺の環境 変化と遺跡内の生業活動の変化などについても, 豊富な デー夕をもとにより具体的な議論ができるようになっ た. 国際会議でも当時は, 日本の文化財研究の緻密さに 対して, また文化財の重要性をよく理解した行政に支え られた緻密な研究が注目された。 また, 遺跡保存に対す る行政的支援も高く評価された。 たとえば，千葉県千葉 市の荒屋敷貝塚では高速道路予定地に貝塚遺跡が立地し 
ていたが，これがトンネル工法によって保存されたこと に対して, 当時海外の研究者は日本の古文化財行政に驚 きをもって称賛した。

高度成長時代が一段落した今日，関係者は発掘の二面 性を考えねばならない状況にある，発掘することで本物 の遺物・遺跡が目の前に展開され，真実の蓄積が進むと いう利点がある反面，目認しえた範囲のみが記録され， 見逃した資料やよく保存できなかった資料もある．現在 の技術では発掘した遺物を状態よく保存する見通しが困 難な場合には，後世に委ねることも必要である，たとえ ば，貝層や地層の剥ぎ取り法は発掘後も堆積状態を確認 でき，そこから遺物を取り出すことも不可能ではない． 半面土ごと取り上げる標本の保管法は場所をとり難儀す るかもしれないが, 後世の研究のためぜひ残してほしい ものである．同様に低湿地遺跡など貴重な遺物が多く出 土する遺跡は，可能ならば範囲確認程度に限定して遺跡 を保存し，後世に委ねるのが賢明であろう。

遺跡に関する新知見は多くの人々の関心を集めてい る. 特に最新の分析技術は，考古学に新規な知見を提供 するばかりでなく，新複合領域としてさらに発展してい く可能性もある. 半面, そのような最新技術は, 必ずし もすぐに考古学へ応用できるとは限らず，遺物のもつ特 有の困難さなどもあり，一つ一つ問題点を解決しながら 進むことも必要である. よく先人達から言われたよう に，「考古学も科学でなければならない，必要条件だけ ではなく(A であれば B と言える)，十分条件も満たす （B という以外のあらゆる可能性が否定できれば A が原 因と言える)上う常に努力することだ」という点は，常 に心掛けたいものである。

この点, 筆者が理学部に属し, 第四紀学の中核をなし ていた自然地理学や古生物学の人達と同じ建物の中で緊 密にご指導していただける環境にあったのは幸運なこと だった，個々の発掘報告書では，その時点での求められ た結果しか記述されていないことも多かったので，もう 一度第四紀学という観点から, 縄文人の多様な生活技術 について全体を見通し，また今後の研究課題も提示する.

\section{II. 貝殼成長線の研究}

\section{1. 貝殼成長線とは何か}

成長線解析を始める出発点の疑問は, 成長線の周期性 一体内時計的な周期性か，潮汐などの影響を受けた障害 輪なのかという問題であろう。生物学的には，サザエの 蓋の成長線の研究 (Uno, 1962) にみられるように, 海の 中でも太陽エネルギーの周期性が 1 次生産者の行動の
基本にあり，捕食動物もその影響を受けているため，日 周的行動が基本のように思われる。もっとも潮間帯に生 息する貝にとって, 干出は貝殼形成の中断を余儀なくさ れるものであり，その障害輪が明膫なため，むしろ潮汐 周期で成長線解析をしたほうがよい種も多い (Evans, 1972 ; Ohno, 1989)

筆者が貝喨成長線の研究をはじめたのは，茨城県土浦 市上高津貝塚の発掘に参加したことに端を発する (小池, 1972)。上高津貝塚はヤマトシジミが主要な貝種であっ たが，ヤマトシジミは成長が遅く，また夏と冬の成長差 が 2 倍程度と小さく冬輪を検出することはかなり困難 だった。一方，ハマグリの場合には成長が早く夏季の早 い成長期と冬輪との差は約 10 倍に達するので, 冬輪の検 出が容易で季節推定には向いていた (Koike, 1973a, b).

このように貝殼成長線の研究を始めようとしたとき, ハマグリから手をつけたのは大変幸運なことだった，八 マグリは水産試験場などでも重要な貝類資源として位置 づけられており，生体染色実験を干潟で行ない，毎月定 点から採取した貝殼を送っていただいくなど，熊本県試 験場や地元漁協などの協力が得られ，自身の研究開始当 初から学際的なアプローチができたことには，大変感謝 している.

また, 米国デイーク大学の Carl Wilbur 教授の研究室 に留学し, Bio-mineralization (生体石灰化) の基礎的研 究 (Wilbur and Yonge, 1964) に携わることができた. 当時主流だった脱灰説 (成長線は貝が閉口し酸化状態で 成長面が脱灰されてできる) (Lutz and Rhoads, 1977) ではなく，走査電子顕微鏡 $(\mathrm{SEM})$ 下では成長線部分が 有機物膜 (コンキオリン膜) の部分とその直後に形成さ れる結晶質部分のセット（Koike, 1986a）であり，貝殼 形成の開始にコンキオリン膜が大きく関係していること を示唆した(図 1).

\section{2. 貝殼を用いた酸素同位体分析}

遺跡出土の貝殼を用いて, 酸素同位体比 $\left(\delta^{18} \mathrm{O}\right)$ によ る古水温の測定を試みることは，伴出土器から時期もわ かり，また遺跡周辺の海況環境変化を知るうえでも興味 深い. 文部省特定研究「古文化財」の研究プロジェクト に，この貝塚出土貝殼を用いた酸素同位体研究が参画で き，鎮西清高先生を代表に個性的なチームが協力して (鎮西ほか, 1980), 旧東京大学海洋研究所の質量分析器 （堀部・大場，1977）でチョウセンハマグリを用いた過 去 9,000 年間 (未補正の ${ }^{14} \mathrm{C}$ 年代) の海水温変化が描か れた (Chinzei et al., 1987). 後水期の海面上昇によって 形成された初期の貝塚である神奈川県横須賀市夏島貝塚 


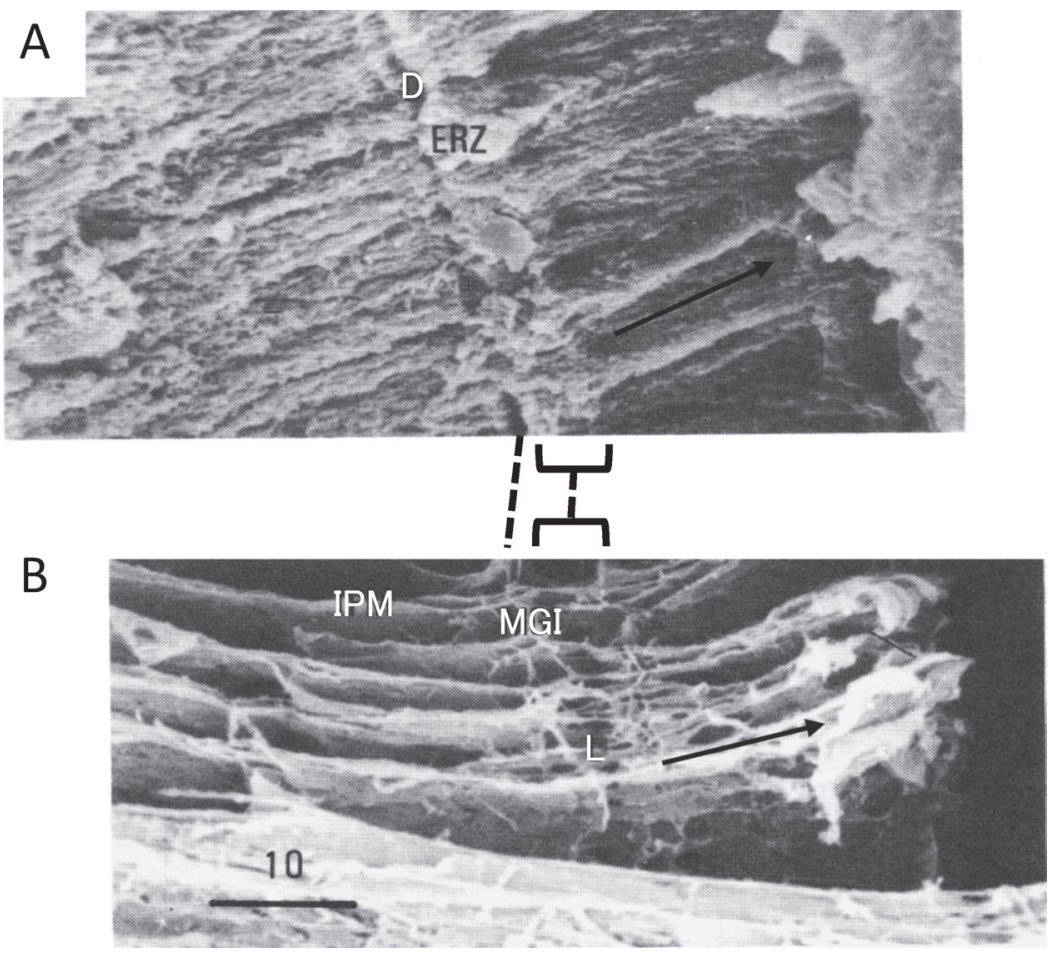

図 1 Mercenaria mercenariaの貝殼成長線の構造 (Koike (1986a) より引用)

A EDTA で脱灰し, 直後に有機物除去を行った貝殼断面の SEM 像. ERZ： etch-resistant zone (エッチ ング耐性ゾーン), D : fine depression (微細な凹み)。 ～は growth increment (日成長)の成長方向を示す. B A と隣接する部位の有機物完全除去処理をした後 Freon 固定した SEM 像. IPM : interprismatic membrane（プリズム型結晶を囲む膜），MGI：organic membrane of the growth increment (日成長の有 機物膜), L : Lace-line zone.

ではまだ海水温が低かったが，縄文海進期時の古海水温 としては 7,000 年前が最も高く, 4,500 4,000 年前に やや寒冷な時期もあったことがわかった．また，縄文か ら弥生時代の変遷期の $2,500 \sim 2,000$ 年前には温度変化 が大きい不安定な時期であったことが示された。

\section{3. 貝類採取の季節性}

貝殼成長線解析の初期のテーマは，縄文時代の貝類採 取の季節性だった．著者が最初に分析対象とした上高津 貝塚 (Akazawa, 1972) は混土貝層のような斜面の二次 堆積の貝層で, 種々の季節の貝殼が混じりあい, “春の 後半がピークで，その後季節に沿って次第に減少するも ののほぼ 1 年中貝類採取を行う”という標準的な貝類採 取の季節性が良く現れていた，その後各地の貝塚を分析 しても，貝類採取がこのような季節性をもつという考え は変わらなかった. やがて, 堆積層準が 1 次堆積層とし て良好に残存している場合や，住居址やピット内貝層の 場合のように比較的短期間に堆積した貝層には，それぞ
れの廃棄行為に相当する季節層が検出され始めた (小池, 1979).

一方，大貝塚の斜面堆積でも，多量の貝を単一季節内 に廃棄した堆積速度の速い層準では季節性が検出され る. 前述の荒屋敷貝塚の高速道路建設にともなう貝塚卜 ンネル部分の発掘箇所 (千葉県文化財センター, 1976) からは，比高 $10 \mathrm{~m}$ にわたる単一季節性の貝層が続いて おり，活発な貝類採取を伺わせた (図 2)。

東京都港区の伊血子貝塚の発掘は，焼かれた貝類や破 砕貝が頻繁にみられ，貝をその場でたき火しながら者て 処理した作業場の跡とされた初めての遺跡だった．わず かな土器以外に生活用具の出土が極端に少なく, 海岸近 くの貝採り作業場と考えられた．伊皿子貝塚では，下層 から上層にかけて貝類種が，マガキ主体の河口干潟の貝 類組成からハイガイ主体の検度のやや高い河口干潟， シ オフキやアサリなど砂泥底干潟の貝類へと変化し, 未発 達な河口干潟の少資源の貝を取りつくしながら新しく参 


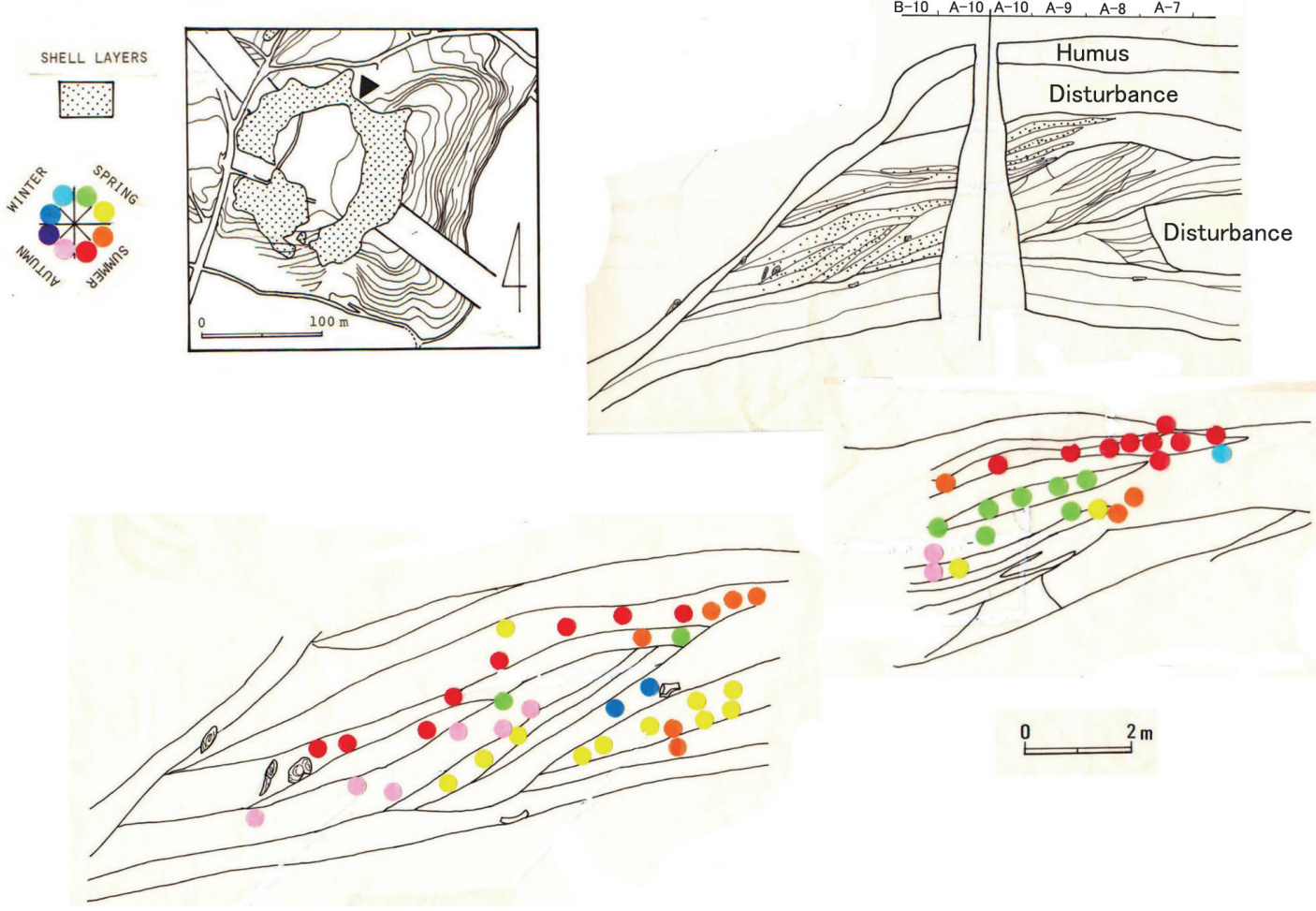

図 2 千葉市荒屋敷貝塚縁辺部における単一季節層

入した貝類を採取していく様子がうかがえた(小池, 1981).

伊血子貝塚の発掘知見は, 貝類採取の季節性にも再考 を促すものだった．貝類採取は対象の貝塚集落内だけで 収束するものではなく，貝採り作業場の可能性が季節性 の分析によって示唆された，潮位差が大きい春の終わり から初夏にはより低潮位に生息する大型のハマグリも採 取でき, 生態学的には最盛期と考えることができるが, 1 年中貝類採取をしている大貝塚の解離採取の季節性に はむしろ最盛期の時期が減少しており，伊血子貝塚で示 唆されたような海岸付近の作業場で貝の処理が行われた 可能性も出てきた。このような春の後半から夏の前半に 採取された貝が少ない集落遺跡は関東の大貝塚には多く みられ (小池, 1983a)，海岸近くの作業場に移住し集中 的に貝類採取をした可能性があることから，貝類資源の 重要性が増大したことをうかがわせる.

貝塚形成には，大規模発掘が盛んだった当時，集落内 で消費したと考える「貝塚負淠」と，集落間の交易ま でも視野に入れた「むき身説」の論争があった，筆者が 後述する生業動態では, 貝類資源を貧乏説に近い考え方
を取っているが，大貝塚が形成される時期の貝類採取 は, 海岸地域の集落では自給食料という役割だけでな く，それを上回る相当量の貝類生産，つまり Intensive な貝類採取は地域の特産物として交易にも用いたのでは ないかと今は考えるようになった，貝には栄養学的に陸 獣にはない塩分やミネラルを多く含み，でんぷん質主体 の堅果類を補う不可欠な食料であるからである.

\section{4. 季節層の推移から生業日誌へ}

もともと採取された貝のうち, どの程度が貝塚に残つ ているのだろうか?この問いに答える方法として, “貝 合わせ valve-pairing” (Koike, 1979) を思いついた. 野 生動物の再捕獲率などでも使われている $\mathrm{S}_{2} / \mathrm{T}_{2}=\mathrm{S}_{1} / \mathrm{T} 1$ $\left(\mathrm{T} 1=\right.$ 母集団, $\mathrm{S}_{1}=1$ 回目の捕獲個体数, $\mathrm{T}_{2}=2$ 回目の 捕獲個体数, $\mathrm{T}_{2}=\mathrm{S}_{2}$ の中の再捕獲数) という単純な比例 計算方法を用いたものである. 千葉県船橋市の夏見台遺 跡の古墳時代の住居址内内貝層 (Koike, 1979) では周辺 の貝の保存性は低く, 貝層の中ほどでは $90 \%$ 以上の保 存率であった，貝層は周辺から脱灰して溶けていくが, 純貝層の内側ではほぼそのまま残存されていると考えて も差し支えないのである.この貝合わせの方法は, 獣骨 


\section{北海道釧路市東釧路貝塚指定範囲外貝層}

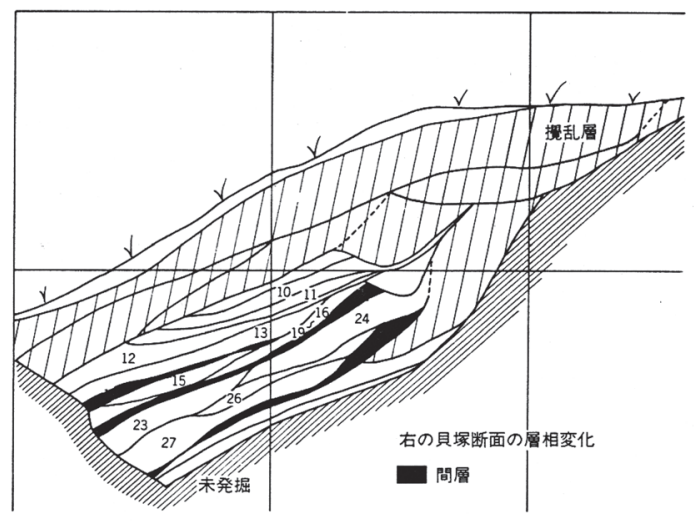

の下顎の左右の pairing や，土器の口縁部の隣り合う土 器片での pairing にも保存率の查定へ応用可能であり, 今後土器生産量の推定などに試みられることを期待した い.

詳細な貝層発掘 (Microstratigraphic excavation) は, 季節層の堆積状況が明らかになり, 季節層の推移から堆 積速度ばかりでなく“年変わり” (Change of the year) もみえてきた. 宮城県東松島市の里浜貝塚の例 (Koike and Okamura, 1994) では, 1 2 m のマウント型の堆 積で, 家族 (住居) 単位の生活廃棄物が基本であり, 自 家消費程度の廃棄単位をもつ貝類の利用と考えられた。 季節的貝層の推移をみると, 春にはやや大型の貝で構成 され，季節が進むと魚骨や黒曜石片も介在しながら，最 上層の貝はやや小型化し，炭化物層がそれを覆い 1 年 の周期となる傾向がみられた．このような貝層の季節性 および炭化物層を年変わりの層として 1 年間の連続し た堆積を追うことができ，貝の示す季節を時間軸とし て, 211 層の細分された層において, 10 回の年変わりが みられた，炭化物層は貝層堆積の休止期であり，休止期 間の長さは不明ではあるが，発掘された範囲の貝層にお いて時間軸を設定することができるようになった.

この里浜貝塚の分析のあと, 北海道釧路市の東釧路貝 塚 (小池, 1985, 1987a) では, 貝層の堆積の間に魚骨層 が介在し，また年変わりとされた貝類採取の停止期には
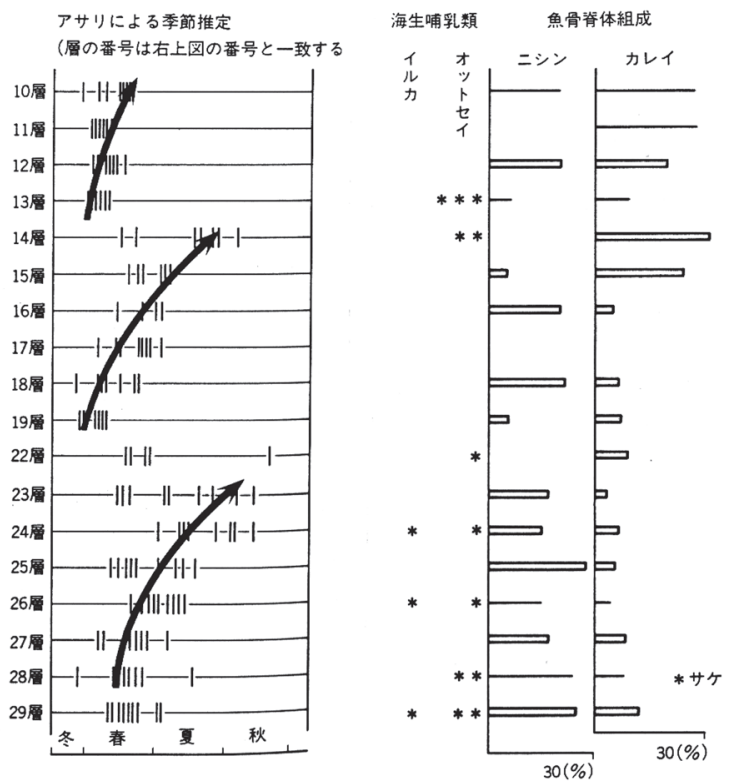

図 3 東釧路貝塚の貝層断面とアサリによる季節推定・伴出動物遺体 (小池 (1987a) より引用)

海獣骨の出土もみられ, この経験から生業日誌 (Exploitation diary)への展開が開けてきた (図 3). 具塚断面 の前に立って, 遺跡の全体の堆積状況や人々の生活も視 野に入れて解釈するようになったのは，第四紀研究者が 野外で観察を続け，ダイナミックな地形変化を見つけ出 す, そのような人達とフィールドワークで出会った経験 に刺激されていることは間違いない.

\section{5. 分層発掘 Microstratigraphic Excavation}

貝塚の発掘は多くの動物骨や土器片・石器片を含み, またふるいにかけないと検出されないような微小な骨片 や植物遺体にも注意を払う必要がある. 科研費「季節推 定法に基づく貝塚調査法の開発」（1983～1985 年）では, (1)貝層面など調查部分には足を踏み入れないこと，(2)魚 骨や炭化物の挿入についても面的に記録する, (3)貝款層 の細分化：貝層堆積の休止期を “貝が寝ている”（貝殼の 上面が揃う), 急速な堆積状態“貝が笑っている”（貝喨 同士が絡み合っている) といった情報も取り入れなが ら, 層位の細分化や微小遺物の保存のための発掘法の開 発を試みた。初年度は千葉県市原市の西広貝塚での貝層 の細分化 (小池, 1983a), 次年度は北海道釧路市の東釧 路貝塚 (小池, 1985) で海獣骨や魚骨の多い多様性に富 んだ貝層の発掘法でExploitation diaryを考え，最終 年度は秋田県本荘市の菖蒲崎貝塚 (本荘市教育委員会, 1985）で低湿地遺跡の発掘法を試みた。最終年の低湿地 
性貝塚は季節推定の結果, 大半が 2 次堆積で遺物は良 いものが入っていても気をつけなければならないことを 知らされた遺跡だった。

丁寧な貝層の発掘は思わ䀦副産物も提供してくれた。 埼玉県浦和市 (現ささいまた市北区) の住居内貝層 (浦和 市遺跡調査会，1985）では，その貝層上面にところどこ ろ柱状の攪乱と思われる穴が見つかった．この攪乱が住 居床面まで届くかを識別していくと，貝層廃棄当時まで に残っていた柱とすでに抜かれた柱穴とが分別でき，最 後に使われた住居の間取りを推定する手がかりが得られ た．貝層の堆積方向から，奥の方から貝殼が堆積し，入 口方向へ後退しながら貝殼を廃棄したと推定され，住居 の埋積状況も知るよい手がかりとなった.

住居址の復元に関しては，第四紀の研究者が野外調查 に使っていた土壤硬度度計を住居址床面に応用してみた こともある (Koike, 1983). 床面の測定は，(1) 発掘作業 の影響が出ないよう掘りあがった面をすぐ測定する, (2) 耕作などの微細な攪乱層を測定值からはずすなど注 意すると, 東京都小金井市はけうえ遺跡の手鏡型住居址 の入り口や炉・壁際などの構造の復元に役立つことが分 かった(小池, 1983b)。このような土壌学の手法も, 遺 跡発掘でぜひ取り入れてほしいもののひとつである.

千葉市の神門貝塚の発掘 (千葉市教育委員会, 1991) は, 筆者が発掘調査に直接参加できる最後のものと考え, で きる限りの各種手法を意欲的に取り入れた，神門遺跡は 主として縄文時代早期の前半の遺跡で, 海岸砂の上に貝 層が堆積したが，そのあと縄文海進により地下水面下に 位置するようになった低湿地性の貝塚 (water-logged site）であった.ここでは火山灰や風成砂など自然堆積物 の層を検出し, 大区分の層位 (ローマ数字 I, II, III など) とした．これは広域に分布するので，遺跡全体で対比が でき，水平な同時間面が決められる，中区分は廃棄等の 行為によりマトリックスとして貝や自然遺物が堆積して いる状態 (貝層など) をさし，1，2，3 とアラビア数字で 区分した，小区分は，中区分のマトリックスが堆積した 後，人間活動などで変性したものとした．これは点在す るので，時間的前後関係がわからない，たとえば，破砕 貝層は中区分の貝層の一部が，上部でたき火が行われた り通路になったりしてみかけが変質しているので，その 一つ一つに a, b, c と付けていった. また動物の巣穴道 や植物の根などによる攪乱も，後からの攪乱としてこれ に含めた.

神門貝塚では, このような発掘法や貝殼成長線による 季節推定のほか, 魚骨分析, 後述のシカ・イノシシの推
定年齢と死亡季節の推定, 獣骨の切痕の分析, 土器の脂 質分析, 土器の $\delta^{13} \mathrm{C}$ 測定を行った。 また総括として, 環境復元を担当した各執筆者が花粉・珪藻・土壤・テフ ラ結果をもち寄って議論しながら村田川低地の古地理の 変遷を総合的に復元した. 次に遺物分析からみた生業活 動の変化と，その詳細な環境変化とを比較検討した． 縄 文早期のイルカ骨が集積した時期は最も海域が広がった 時期で魚骨も回遊性のものが多かった．前期には高位海 水準に堆積物の埋積が始まりラグーン的性格の前浜と砂 質の後浜が発達し，環境の多様化にともない貝類採取が 盛んになり，魚種は内湾性のものを主体に豊富になった など, 出土動物相と環境変化との因果関倸や生業間の影 響などを皆で議論したのは思い出深い.

\section{6. 貝殼成長線解析の展望}

貝殼成長線を観察するには，(1)貝殼を計測し，(2)中央 線にそって貝殼をダイヤモンドカッターで切断し, (3)切 断面を研磨し，(4)レプリカ法の場合には表面を少し脱灰 してからスンプ法でレプリカを作成し，(5) 100 倍前後 で検鏡するというプロセスを踏む.レプリカの作成は, ある程度の知識があればできるので作業を依頼すること もでき，集中的に貝殼成長線解析を行っていた埼玉大学 時代には “レプリカ工場” と称し放課後毎日 10 人以上の アルバイトを雇い，大規模発掘で得られた大量の貝殼を 用いてレプリカを作成し観察していた。この頃生まれた のが “Concho-chronology” (貝殼年代学)のアイデアで ある (小池, 1983c)。これは, 同一地域から採取された貝 殼では, 日成長量の変化が非常に似ていて, 冬輪パター ンや特徵的な障害輪などのイベントを指標にして，同じ 干潟から貝類を採取したと考えられる近接した集落間で 冬輪パターンを対応させ，より長い時間軸を設定しよう とする試みである。たとえば，千葉県市原市の西広貝塚 と近隣する祇園原貝塚とはともに養老川流域にあり, 具 殼に現れる気候変動と両集落間でみられる人口変動とを 比較することは大変有意義なことだと考えたが，まだ道 半ばの状態で挫折している. 大量の貝層ブロック標本が 各地で長年保管されていると聞き，文化財行政の大変な 状況を鑑みて痛恨の思いであるが，今後の研究のため, ぜひ保管を続けていただきたいと願うばかりである。

貝殼成長線解析はひとつひとつの貝殼について成長線 を計数する手間㗇のかかる方法であるが，最近注目され ているマイクロ X 線 CT スキャン ( $\mu$ CT-scan) (LeissHolzingor et al., 2015）を用いて, 九州国立博物館で測 定した.この $\mu \mathrm{CT}$-scan は, $1-5 \mu \mathrm{m}$ の分解能をもつた め, 顕微鏡レベルの解像度をもち, 非破壊的に全体を撮 
影した後は，3 次元的にどの面からも観察でき，また成 長面が屈曲してもそれぞれの直交面を設定して連続した 画像を構築できるため, 成長線解析が飛躍的に容易にな ると期待される．まだ試行錯誤の状態であるが，顕微鏡 で無意識で行っていた明度やフォーカスの調整は，パソ コンの画像処理により容易に見やすい画像に加工でき, この非破壊法で自動カウントや自動日成長の測定も可 能になる時代がすぐそこまで来ているように思われる (図 4).

\section{III. 歯による年齢査定と捕獲圧}

\section{1. 歯の年輪による年齢査定}

野生動物の年齢はカモシカの角の年輪のように外見か ら判定できるものもあるが，一般に年齢査定は手間がか かる．一般的な年齢查定としては歯など連続形質にみら れる年輪が用いられる. 特定研究「古文化財」の第 2 ラ ウンドプロジェクトでは, シカ (小池・大泰司, 1984), イノシシ (小池・林, 1984), 海獣類のセメント質年輪 を使った年齢查定も試みられた (内藤・小池，1984）。

また年齢査定された歯を用いて，咬耗状態を調べ年 齢推定用の標準的咬耗度を設定すれば, 歯の咬耗度の 観察だけで年齢が推定できる簡便法もある (Koike and Ohtaishi, 1985).

図 5 に九州国立博物館で測定したCT-scan による象 牙の年輪像を, 図 6 に ultra- $\mu \mathrm{CT}-\mathrm{scan}$ による現生ツキ ノワグマの臼歯セメント質年輪を示した，予察の段階で はあるが, 今後 X 線強度や分解能を調節して, より鮮明 な像を得るよう工夫すれば，今まで剥片作成が必要で あった歯の年輪による年齢査定・季節推定などが，非破 壊で多数個体を処理することも可能になると期待される.

\section{2. 捕獲圧分析}

捕獲圧 (Hunting pressure) とは，ある時代の食糧資 源 (Paleo-biomass) と人口とのバランス関係を示す指標 である(Koike and Ohtaishi, 1985, 1987). 捕獲圧は, (1)現生野生生物の個体群の年齢構成から得られる生残曲 線 $l x$ をもとに, (2)遺跡出土の獣骨を試料とした場合には 死亡分布曲線 $d x(=1000-l x)$ を算出し, (3)それを個体群 全体として指数化した生残率 $S x$ を用いて, 非狩猟下保 護個体群 (生残率 0.871 ) から各遺跡での生残率を差引 した值である (小池, 2000 参照)。

多数にシカ下顎骨を出土した 18 遺跡で, 歯の咬耗度 から捕獲圧を調べたところ (小池, 1992a)，広島県庄原 市にある帝釈峡観音堂洞窟の旧石器時代の層準や縄文時 代早・前期の貝塚では 0.8 前後の生残率で, 狩猟圧はさ
ほど高くなく，当時の人々が必要とした食料に対しシカ 資源は比較的豊富であったと推測された。一方, 縄文時 代後期になると生残率は $0.74 \sim 0.73$ となり, 捕獲限界 をやや超える生残率を示した．シ力資源量 (密度) は山 の生息地に入ると粪の密度や食痕から容易に感じ取れる ものである.この時代にはシカ資源量が減少しないよう メスの捕獲を制限するなど狩絧に対して規制しながら調 整していたものと推察される. 一方, 弥生時代やオホー ツク文化期の遺跡では，捕獲限界を大きく超える生残率 を示し, シカ資源の減少をまねき個体数の回復にはしば らく時間が必要であったと推察される. 北海道根室市オ ンネモト遺跡では, 当歳獣の出現頻度が非常に高く, メ スが優位に多かったこと, 狩猟季節が冬期主体であった ことなどから, 越冬地の群れの中心部をねらって一勢捕 獲した可能性が考えられ (小池・大泰司, 1984), 縄文 時代の弓矢や落とし穴を用いた狩猟技術やシカ資源の位 置づけとは生業戦略が異なってきたとも考えられる.

また, 新潟県旧巻町の豊原遺跡の調査 (小野ほか, 1988) では, 多数のシカ下顎骨が密集して発掘され, セメント 年輪による捕獲季節が冬季だったことから (松井ほか, 1991），縄文時代においても積雪を逃れてきたシカの群 れを集中的に狩猟するという Hunting siteの可能性が 示唆された.

\section{3. 生業動態分析}

生業動態 (Exploitation dynamics) 分析は, 生態学に おける動物個体数の増減を推計する個体群変動とその変 動要因として餌資源の変動を関連づけようとする個体群 動態学 (Population dynamics)の考え方を, 人類史に おける生業活動と食料資源との動態へと発展させたもの である.

約 1 万数千年間におよぶ縄文時代の歴史の中で，縄 文人の生業戦略の基盤となる生活技術の諸要素は, 縄文 時代早期頃までにほぼ完成したと考えられている。 した がって, 縄文時代早期以降の各時期にみられる生活文化 の変化は, その時々の地域集団が人口の増減および地域 環境における食料資源の状況に応じて，幅広い生業戦略 システムの中から最適な生活技術を選択採用した結果と も考えられる. 生業動態分析の目的は, 先史時代人の人 口変化および食料資源の状況が，生業活動としてどのよ うに選択されたかを解析しょうとするものである.

生業動態分析は, (1)対象地域の遺跡人口を正確に把握 する人口動態分析，(2)当時の食料対象となった動植物 を, 内水面生態系バイオマスと陸上生態系バイオマスか ら復原するパレオバイオマス分析, (3)人口動態と食料資 

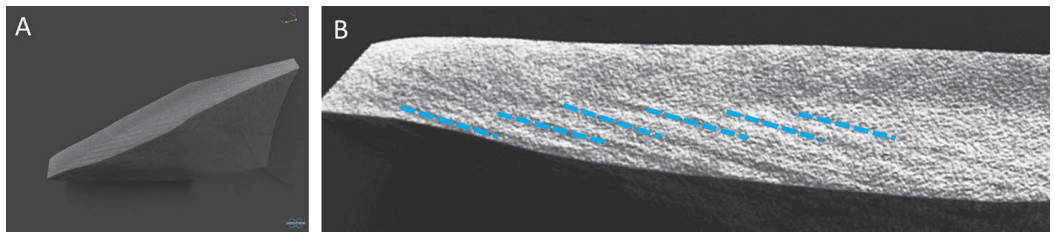

図 4 九州国立博物館で撮影された $\mu$ CT-scan による現生チョウセンハマグリの貝喨成長線 $\mathrm{A}$ ：貝殼断面像，B：断面上の成長線.
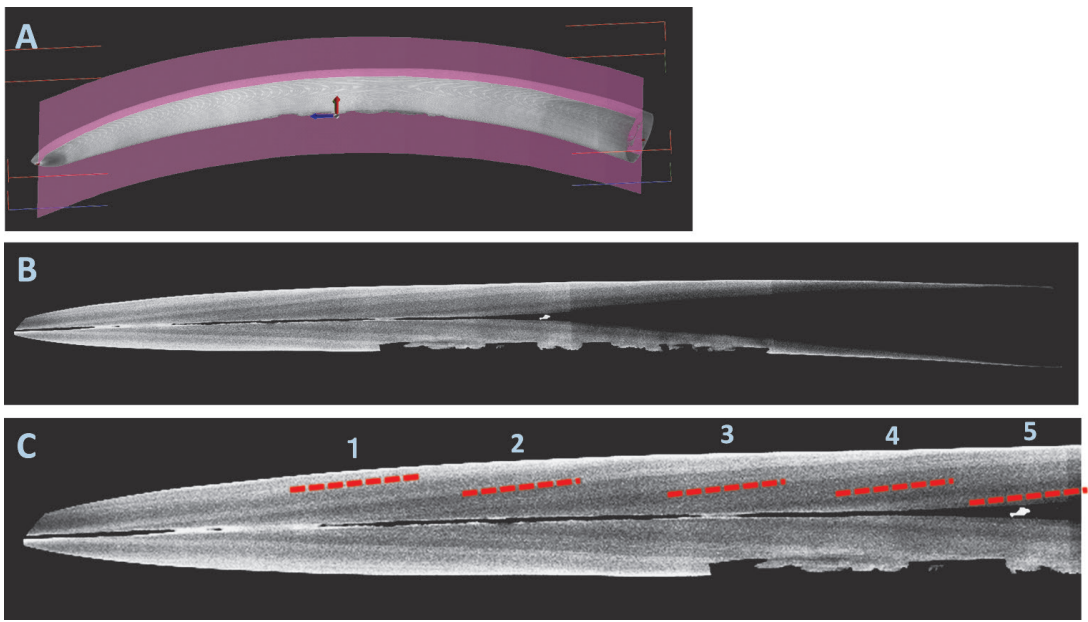

図 5 九州国立博物館で撮影された CT-scanによる象牙の年齢査定

A : 象牙歯髄脘にそったポリラインの設定, B : ポリライン上の断面像 (下面の凹凸は彫刻による), $\mathrm{C} ： \mathrm{~B}$ に扔ける年輪。
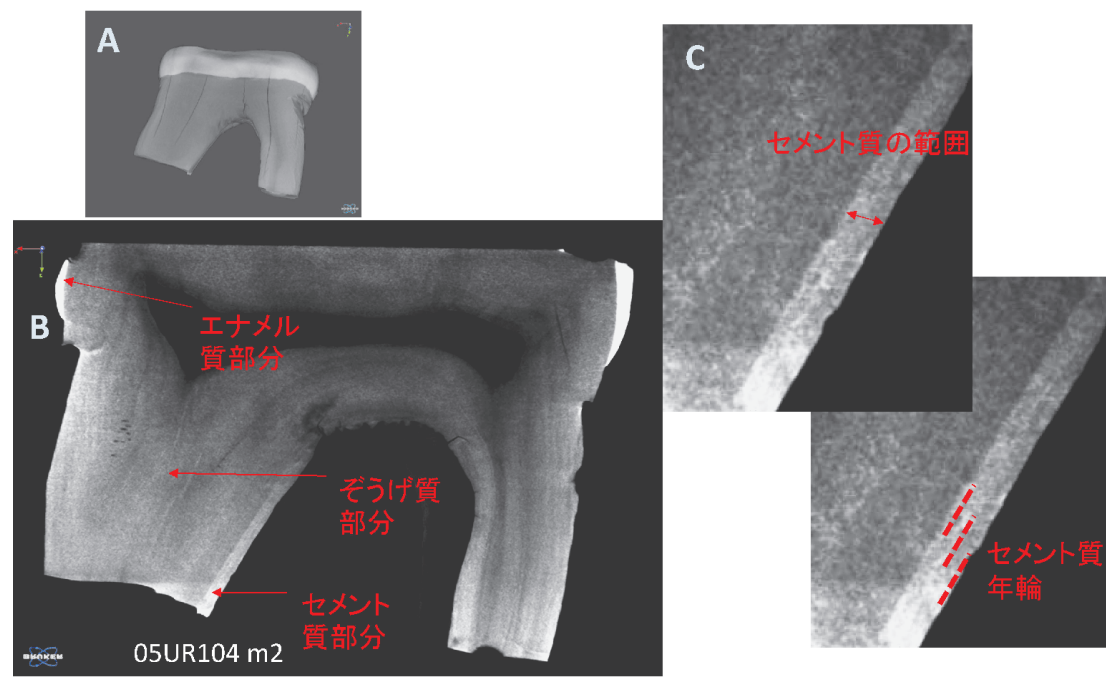

図 6 九州国立博物館で撮影された ultra- $\mu$ CT-scan によるッキノワグマの大白歯 (M2)の年齢査定 $\mathrm{A}$ ：外見，B：合成断面の像，C：セメント質に扔ける年輪. 
源のバランスの指標となる捕食圧の推定, という 3 つの プロセスから構成される (小池, 2000 参照).

人口動態については, 縄文時代各時期の貝塚数の変遷 （樋泉，1999）や，第四紀地図中の縄文時代中期の遺跡 密度分布図 (日本第四紀学会編，1987）のほか, 地域と 時期を区切っての詳細な遺跡密度変化の試みが各地域で 行われており，これらが生業動態の基礎資料となる．縄 文時代の人口変動は，地域によっても異なる．関東地方 の貝塚数は, 縄文時代前期や後期に比べ中期に一時的に 減少するという考えが定着しつつあることは，海退によ る貝塚の低地への移動とその後の海進による遺跡の消失 (埋没)の可能性からも, また, 前述の貝殼の $\delta^{18} \mathrm{O}$ 分析 からみても興味深い.

先史時代の人の生活環境を考える際の環境復元では, 特に食料資源となった動植物がどれくらい分布していた のかが重要で，その復元がパレオバイオマス解析である (Koike, 1986b)，幸い過去の地域生態系の一次生産者で ある花粉や珪藻などは，いわゆる微化石としてよく研究 されてきた(辻ほか，1992）。

貝類資源の場合には古海水温変動や貝類の餌である珪 藻の組成などが基本デー夕になる，小杉 (1985) は現在 の東京湾に生息する珪藻分析の結果をもとに, 外洋指標 種群や汽水砂質干潟指標種, 汽水砂質干潟指標種群など 11 群に細分し，有用貝類の分布を復元した．例として 縄文海進期に相当する黒浜期の北関東地域の貝塚の分布 （小杉ほか，1989）をみると，湾奥部にはヤマトシジミ を産する汽水化した干潟が出現し, 東海岸ではアサリに 適する砂質干潟, 西海岸では八イガイ, マガキ, ヤマト シジミを産するやや泥質の干潟が発達し，湾口部の東海 岸ではより砂質の干潟が発達しハマグリが主構成種で あったなど，貝塚構成主体貝の分布とよく一致した。 ま た資源量的には，湾奥部では比較的小さな海水準変動で も貝類資源が影響を受ける小規模のものだったが，内湾 性の砂質干潟ではバイマスも大きく安定した食料源を提 供したと推定された (松島, 2012).

動物個体群動態学によれば, 対象動物個体群がその地 域環境のもつ環境収容力 (Carrying capacity, または K レベル）よりも低い密度にあるのが「増加期型個体群」 で，環境収容力とほぼ平衡あるいは若干それを超えてい る状況にあるのが「安定期型個体群」と呼ばれる。 また $\mathrm{K}$ レベルを大きく超えてしまって極端な個体数の減少が起 きたものは「Crush 個体群」ともいう。これらの増加期 型集落と安定期型集落の特徴を図 7 にまとめて表示した (Koike, 1992)。食料事情が環境収容力 (Kレベル)より
低いか，ほぼそれに達したかで両個体群が識別される。 ヒトの場合には，食料源も多様であるため，個体群の状 況の違いは食料の選択性や, 競争関係の増加による社会 関係にも大きく現れるであろう．食料資源が豊富な増加 期型個体群の人々は, 栄養価が高く美味な “Favorite foods”や“Primary foods”を主要な食料とすることが できる. Primary foods に選択される動植物種は，採 取効率が比較的よく, 年間変動が少なく資源的に安定し ているものが選ばれる，縄文時代人には，植物食料とし てクリや堅果類など収穫量の多いもの, 動物食料では長 い寿命をもつシカ・イノシシなどが Primary foods と して選択されたと考えられる.

一方，安定期型個体群になると，高い生産量をもち捕 食圧に対する耐性のあるものがより重要になり，日本の 狩猟獣の中では 1 年 1 仔のニホンジカよりも多産なイ ノシシや，あるいは高い再生産能力をもつ小型獣が増し てくる. 高い基礎生産力をもつ貝類や魚類は典型的な $\mathrm{r}$ 戦略型 (増加率の高い種) の生物で, 重要な secondary foods と考えられる. 環境収容力を超えてさらに人口が 増加した場合には, “occasional foods”にまで手をつけ なくてはならなくなり，あく抜きに手間を要するが貯蔵 に適するトチの実や，環境劣化に強いカエル，ネズミな どの小型動物がそれに相当するであろう。このように貝 塚出土動植物を詳細に復原することは, 当時の人々が周 辺環境の提供する食料資源の中からどの夕イプをどの程 度まで利用し，食料供給を満たしていたかを探る重要な 基礎的作業である。

生業動態を示す最も良い指標は，前章で述べた捕獲圧 である。 シカ資源が縄文時代人に Primary foods とし て選択されていたとすれば，このような Primary foods に余裕がある状況のヒト個体群は増加期型であり, 飽和 状況に達した個体群は, 典型的な安定期型個体群と考え られる. 多数の貝塚が形成された古東京湾では増加期型 から安定期方への移行が何度か訪れたのは興味深い.

生業動態の状況は季節性にも表れてくる. 生業の季節 性は, 本来対象動植物の生態的特徵に合わせて最も効率 のよい季節に採集するものである．しかしながら，特定 種への依存度が高まると, 生態学的最適季節のみなら ず，より長期的あるいは周年採集する傾向が現れてく る. 古東京湾の湾奥部に形成された黒浜期の貝層の例 (小池, 1986) では, 貝層形成開始期 (黒浜 I 期・II 期) か ら出土するヤマトシジミは採集季節が典型的な春から夏 季で，かつ大型貝 $(3 \cdot 4$ 年貝) が多いことから捕獲圧は それほど高くなかったが，最盛期の黒浜而期になると採 


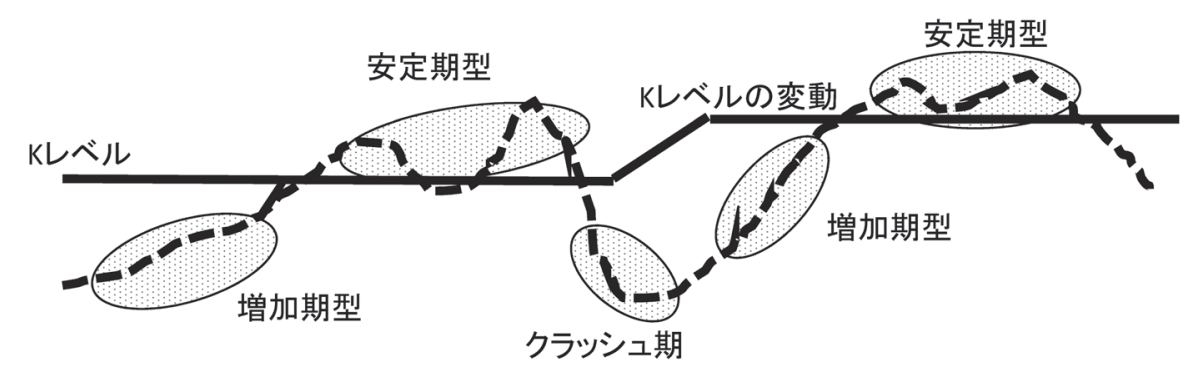

\begin{tabular}{|c|c|c|c|}
\hline & & 増加期型集落 & 安定期型集落 \\
\hline \multirow{2}{*}{ 定義 } & 食糧事情 & K レベルより低い & K レベルに到達 \\
\hline & 人口の特徵 & 人口増加の余地あり & 人ロが飽和/やや過剩 \\
\hline \multirow{3}{*}{ 指標 } & 食料対象 & F avourite Foods, Prim ary Foodsが主体 & Primary FoodsからSecondary Foodsへの移行 \\
\hline & 捕獲圧 & 捕獲限界よりかなり低い & 捕獲限界を若干超えながら調節して確保する \\
\hline & 捕獲の季節性 & 捕獲効率の良い時期に集中 & 周年できるだけ捕獲しようとする \\
\hline \multirow{4}{*}{ 社会的特徵 } & 集落の安定性 & 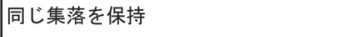 & 主要集落外にも分散、集落間の摩擦が生ずる \\
\hline & 集団内の社会的規制 & 規制が弱く発展的 & 生業上の規制が強くなる \\
\hline & 埋葬様式 & 緩い様式化 & 墓域や拔歯など身分の明破化 \\
\hline & 儀礼用具など & 萌芽的で未分化 & より複雑に多様化 \\
\hline
\end{tabular}

図 7 増加期型集落と安定期型集落の特徵

集季節は周年におよび, 小型化 (2 年貝以下の若年貝) し 未成熟個体が大半を占めるようになり, 乱獲状態に陥っ たと推測される。 ヤマトシジミの殼成長から見る限り生 息環境自体に悪化の傾向はみられず，むしろ縄文海進期 に形成された小規模な泥質干潟の貝類資源をめぐって, 周年採取という活発な採取活動が，具類の年齢構成の若 年化をもたらしたと考えられる．このように捕獲圧と季 節性は相関することが多く， ヤマトシジミのような資源 量の比較的小さい種では, 縄文時代でもヒトの捕獲によ る影響が地域絶滅をもたらすに至ったことを物語ってい る.

一方，人類活動による適度の捕獲は，野生個体群にお いて間引き効果による頭数調整機能があり, 地域個体群 が長く増加期型にとどまることで，ヒトー捕食動物間に 効率的でより安定な sustainable use が成立すると考え られる。貝類資源に扔いても，ヒトが貝を採捕する行動 は砂質底地を耕すことになり，酸素の供給や貝の日常的 な上下移動を助ける。 また，捕獲により間引きは，次の 産卵期まで具資源量を低密度に保つことになり, 具の餌 条件を相対的に良くすることになるので，これも sustainable use に貢献していると考えられる. 植物に関し ても，人類活動は有用植物を選定育成し，より長期的な sustainable use を心掛けてきたに違いない。たとえば,
クリなど堅果類をつける樹木は剪定をすると木を長く活 性化し多くの収穫をもたらすだけでなく，人には然料を 提供するのに役立ってきた.

さらに社会的特徵としては, テリトリー性・定住性の 発達や集団内関係が, 増加期型個体群では開放的であっ たのが，安定期型個体群ではより固定的な集団帰属性が 発達するなどに表れると推察される. 集落間構造 (集落 間でも安定した大集落と一時的な小集落とが共存する) や集落内住居址構成の分析が生業動態との関連性で期待 される，抜歯風習や墓域形成などは, 人の移動が出自な どの要因で制度化されていく過程として, 人口動態から 考えてみるのも一考に值するのではあるまいか．また精 神的な規制の例として土偶や祭祀用具の発達も関連性が あるかもしれない (Koike, 1992).

\section{IV．各種食性分析}

縄文時代人が何を食していたかを知る方法は, 出土し た動植物遺体の種同定のみならず，様々な分析方法が試 みられている. 各種分析法にはそれぞれの特徽があり, メリット・ディメリットがある. 数值化されて結果が出 てくる場合でも, サンプルをどのように精製し，どう測 定するかによって結果が違ってくるので留意が必要であ る. 


\section{1. 脂 質分 析}

筆者の脂質分析を使った研究は, 帯広畜産大学の中野 益男先生の研究室に通い実験方法をご教示いただいたこ とに始まる (Koike and Nakano, 1987). 埼玉大学で抽 出ラインとガスクロマトグラフィーを設置し，また学内 共同利用施設である分析センター (現埼玉大学化学分析 支援センター) のガスクロマトグラフィー質量分析装置 （GC-MS : JEOL GC-MS DX303）を利用でき，多数の 分析が許されたことも幸運だった。

考古学では一般的に脂肪酸分析と呼ばれているが，脂 肪酸は直鎖型の脂質をさし，不飽和脂肪酸は酸化により 変質しやすい，そこで著者は，脂肪酸よりより安定なス テロールを含めて分析してきた。 ここではー $\mathrm{OH}$ 基をも つ生物由来の物質すべてが一般に脂質 (Lipids) と呼ば れるので, 脂肪酸分析ではなく、“脂質分析”と呼びたい (小池, 2000).

遺跡の脂質分析を始めるにあたり，有用食品に関して は成分表が公表されているが，自然生態系のものに関し てはデータベースから作る必要があった，水産動植物の 脂肪酸組成 (小池・土屋, 1988) や野生有用植物等のス テロール組成 (小池, 1991a) を調べ，クラスター分析を して, 対象種の特徵を選び出した。

遺跡出土のものを分析対象とする際の難しさのひとつ は，土壤中にはそこを覆っていた植生が長い年月の間に 腐食され蓄積した植物由来の脂質 (小池，1987b）が高 い濃度で含まれていることである，脂質は水の中では拡 散しにくいものの, 土畩や土器などでは浸透拡散しやす いという性質があり，この土䁃からの脂質の混入は，機 器の性能がよくなり微量分析が可能になったため, なお 一層危険になった．高精度 GC-MS では，たとえばコレ ステロールのピーク（分子量 386 関連のピーク）はどの ような試料からでも検出可能である。コレステロールは 細胞膜成分として基本的には動物にも植物にも含まれて いるからである。

分析対象となるサンプルから抽出された脂質は，長い 年月による土壤中での酸化変成や分解ばかりでなく，食 料として熱変性を受けていることが多い，土器内面付着 物のいわゆる“おこげ”は，熱変性した脂質となり，もと の食品に含まれた脂質を正確に同定するのは難しい，不 飽和脂肪酸は一般に水産動物に多いが，酸化しやすく， また直鎖が切れて順次短鎖化する。これは逆に言うと， 変質しやすい不飽和脂肪酸が好条件下で保存され検出さ れた時は, 鍋型土器のように(瀬川・小池, 1990)，その 不飽和脂肪酸の存在によって水産動物，特に青魚類の存
在を示唆できることもある.

また, 煮沸実験土器の土器片 (小林, 2008)のステ ロール分析では，スープに油が浮くように土器口縁部の 食物上面部分からはコレステロールが，土器下面にいく につれ植物ステロールが多くなる傾向も認められ, 土器 のどの部分を分析するかで結果や解釈が異なることが考 えられる。

土器の脂質分析に一番適した材料は, 古墳の石室から の出土品のようにあまり土に接触しなかった土器で，大 分県国東市の久末京徳遺跡出土の壶型土器では, 目的と したステロールが明瞭に検出された例もある (小池, 1991b)。また，たくさんの土壙の埋積土を測定したが, 直接埋葬土壙墓と判定できる結果は限られており，「も し土壙墓とすればコレステロール比の分布から，頭部や 胸部はこの辺であろう」といった仮設的な結論に終始し た

糞石は, 落とし主の問題はさておき (イヌの場合が多 い), 脂質分析の対象試料としては比較的明瞭な結果が 得られている(桜井・小池，1989)。糞石は比較的短期 間の食事内容を反映するため，その脂質組成にはコレス テロールの卓越したものや，あるいは植物ステロールで 穀物に多く含まれる $\beta$-シトステロールが大半を占める ものなど特徵的なものが多かった (小池，1990a).

当時は GC-MS を用いた分析が主体だったが，近年で はガスクロマトグラフィータンデム質量分析装置 $(\mathrm{GC} /$ MS/MS) という直列に2つの質量分析計を接続したも のも有機物の同定にはよく用いられ，第 1 番目の MS か ら特定のイオンを取り出し，それを解離させて生じたフ ラグメントイオンを第 2 の MS で分析し, 正確な分子構 造を解析できるようになった，分析機器の発達で少量の 目的物からも検出同定がますます可能になってくるが, 前述のように，出土遺物にはあらゆる土鎄中の化合物を 含むことから，目的に合致した部位を試料として厳選 し，また分析材料をよく精製するなど，充分な配慮が必 要である. また GC-MS で得られた特定のイオンをさら に質量分析器で同位体測定する装置も考案されており, 抽出されたコラーゲンが海洋生態系由来か陸上生態系由 来かの分別も可能になると期待される.

\section{2. 炭素安定同位体分析}

人骨コラーゲンなどを用いた食性分析には，現在では 炭素安定同位体比 $\left(\delta^{13} \mathrm{C}\right)$ と窒素同位体比 $\left(\delta^{15} \mathrm{~N}\right)$ の両者 を測定するが，当初筆者らは $\delta^{13} \mathrm{C}$ 分析のみから始めた. カナダ British Columbia 大学の Brian Chisholm 博士 は, カナダインディアンの人骨コラーゲンの $\delta^{13} \mathrm{C}$ 值を 
用いて，食料蛋白源が河口域から遡るにつれサケに対し て陸獣であるシカ類の割合が多くなることを Science に発表した研究者 (Chisholm et al., 1982) である. 同 博士とは, 学術振興会の招聘研究者として埼玉大学にお いて協同研究が始まり, 名古屋大学理学部地球化学の中 井信之先生の研究室の質量分析器で $\delta^{13} \mathrm{C}$ を測定させて いただいた (Chisholm ほか，1988)。この研究を進める にはいかに人骨試料を集めるのが肝心で，全国の人骨を 保管する解剖学教室や人類学教室を訪ねてサンプルを提 供していただいた (Koike and Chisholm, 1991 ; 小池, 1992b ; 小池ほか, 1992a, b). また干潟の生物を網羅的 に測定し（海洋プランクトンの $\delta^{13} \mathrm{C}$ 代表值 $-19.5 \%$ ；藻 の代表值- $15 \%$ 以下 ; 陸上 C3 植物の代表值- $27.5 \%$ ； 陸上 C4 植物の代表値- $12.5 \%$ )，干潟食物網のデー夕 ベースも作成した (小池・中島, 1988, 1989 ；Mitani et $a l ., 2006,2009)$ ．人骨研究では，北海道の縄文時代前期 から近世アイヌまでの炭素同位体比に男女差 (正確に言 うと一部の男性の值が陸上食性にやや偏る) がみられる こと (Chisholm et al., 1993) を発表したが, 統計的な処 理で解明されるような事柄ではなかったためあまり浸透 しなかった

人骨の食性分析は, AMS 年代測定法にも貢献した. 放 射性炭素 ${ }^{14} \mathrm{C}$ を用いた年代測定は，AMS 年代測定法に より分析試料が少なくて済むようになり，また格段に測 定精度が増してきた，問題となるのは，日本は四方を海 に囲まれており，海産物は海洋リザーバー効果を受ける ことである. 人骨年代の海洋りザーバー効果をチェック した例として, 福岡県糸島市の大友遺跡の分析 (Mihara, et al., 2004a）がある. 大友遺跡は弥生早期のドルメン （支石墓）から弥生前・中期の鹤棺，古墳時代の石棺ま で連続して墓域として使用され，比較的保存の良い人骨 が出土した稀有な遺跡である。近隣の岐志元村遺跡にお いて, 同一層準から出土したシカ骨を陸上食動物とし, マダイ骨を海洋動物として比較すると，その AMS 年代 の差が海洋リザーバー効果となる. 一方, 人骨の $\delta^{13} \mathrm{C}$ 值 から海洋生態系食料の比率を算出し, 海洋リザーバー効 果を勘案した年代較正用のプログラム CALIB 4.3 を用 いて，このプログラムにそれぞれの人骨が示した海洋依 存度を入力し海洋リザーバー効果を補正する計算をさせ ると, 補正年代が得られる。 これで弥生時代初頭期の $2400 \mathrm{BP}$ 問題 (大気の較正曲線が不安定な時期) をまた いで，考古学や文献で言われている弥生時代開始年代と 整合的な年代が得られるようになった。

また, 黒色土器に含まれる炭化物の $\delta^{13} \mathrm{C}$ 測定 (Mihara et al., 2004b) により, 黒色土器を作成する際用いる料款 がC3 タイプのイネか，あるいはC4 タイプのコウリヤ ンなどの雑穀かを調べたところ，中国東北地域の C4 穀 物生産圈と中国揚子江沿岸部の C3 穀物生産圈の分布に 分かれた (Mihara et al.., 2007).

土器付着物の AMS 放射性炭素年代測定では, (1)土器 外表面は“すす (煤)”が主成分付着したもので，樹木の 年輪が示す使用年代より古くずれるので，土器編年との 対応には向かない，(2)土器内面のいわゆる“おこげ”は 土器で調理された食料の中に海産物が含まれると海洋リ ザーバー効果で古くなる可能性をもつ. (3)繊維土器のよ うな土器燒成時にできた炭化物に関しては，埼玉県富士 見台市考古資料館提供の水子貝塚出土土器の資料を拝借 して年代測定したところ，編年傾向とは一致しない誤差 の大きい結果 (未発表) で，これは高温下で同位体分別 が起こったものと考えられる。このような同位体分別は 多かれ少なかれ，高温の燃焼下で生成した炭化物には当 てはまるもので，安定同位体を用いて同位体分別を補正 はしているものの，経験的には充分とは思えない例が多 い.

$\delta^{13} \mathrm{C}$ 法のこれからの研究として期待されるものに, 一次生産者の值の変動要因として光合成に用いる $\mathrm{CO}_{2}$ ガスや $\mathrm{CO}^{3-}$ の問題がある. 空気中の $\mathrm{CO}_{2}$ ガスは光合 成の活発な時期には濃度が下がり, $\delta^{13} \mathrm{C} も よ り$ 負に傾 く.つまりオープンな林や草原では空気中の $\mathrm{CO}_{2}$ ガス は標準值のー7\%。保つが, 密閉された森林では, $\mathrm{CO}_{2}$ ガス自体が負に傾き，その結果光合成の生成物である森 林植物も-30〜-35\%。近くまで下がる. アフリカのシン リンゾウの象牙の值 (Ishibashi et al., 1999) や, マレー シアのマングローブの生態調査 (小池, 1995) では, 各 樹齢林の葉のみならず，土䁃中の炭化物も測定され，伐 採された直後の新規若齢林では代表值の $-26.5 \%$ だっ たが，高齢樹林や保護林では負に大きく偏った值だっ た．これを応用すれば，縄文時代の人々の食料が，山の 中の自然林から採集したもの (クルミやトチなど) なの か，クリなどの堅果物を集落内外のやや開けた場所に保 護/栽培したのかを区別することも可能かもしれない (小池, 1992c)

\section{3. 窒素安定同位体分析}

植物や珪藻などの一次生産者の窒素安定同位体 (以 下, $\left.\delta^{15} \mathrm{~N}\right)$ の值は, 基本的にはそれらの一次生産者か吸収 した可給態窒素源の $\delta^{15} \mathrm{~N}$ の值に起因する (DeNiro and Epstein, 1981). そのため一次生産者の $\delta^{15} \mathrm{~N}$ 值は生育環 境によって異なる。また, $\delta^{15} \mathrm{~N}$ は食物連鎖の位置 $($ 栄養 
段階)によって 3 4\%。濃縮することが特徴で, 陸上生 態系はシカなどの 1 次消費者では $\delta^{15} \mathrm{~N}$ 值が比較的低い が, 海洋生態系では一次生産者 (海洋プランクトンや珪 藻など) から一次消費者 (動物性プランクトン), 小型動 物群など食物連鎖の段階が複雑でより高次になるため, ヒトの食料対象となる動物の $\delta^{15} \mathrm{~N}$ 值は $+15 \%$ 以上にな る.

南川雅男先生の三菱生命科学研究所では, 和田英太郎 先生をはじめとする $\delta^{15} \mathrm{~N}$ の研究が進められ, 栄養段階 Trophic level の研究には $\delta^{15} \mathrm{~N}$ が適していることが報告 された (Minagawa and Wada, 1984)。九州大学に転出 してからは ANCA-mass (Automated Nitrogen-Carbon Isotope Analyzer) が入り, 著者の研究室でも $\delta^{15} \mathrm{~N}$ の測 定が可能になり多方面に応用された，関東の貝塚出土人 骨の值は全体に栄養段階が低く (Chisholm and Koike, 1996), オホーツク文化期の人骨では蛋白源がほぼ $100 \%$ 海洋産物であることが示唆された(小池, 2000).

千葉県松戸市の貝の花貝塚の人骨を土器編年に基づき 細分してグループ化すると, 大きな変化が読み取れ, 称 名寺式期には海産物寄りで堀之内期にはやや陸上産物の 割合が増加し栄養段階も下がるが, 縄文時代後期前半に は再び海産物の割合がやや増加した．また出土人骨が比 較的多かった縄文時代後期前半について, 男女に分けて みると, 絶対值では見えてこなかったが, 回帰直線上で みると男性のほうが女性より $\delta^{15} \mathrm{~N}$ が相対的に高かった (小池, 2000).

縄文時代は遺跡内の人骨を土器編年の時期別に区分し てもまだ個体差が大きいのが特徴であるが, 江戸時代で は同一家族内と思われる墓壙から出土した人骨の個体差 はほとんどない。一人一膳の食事は実は公平な食習慣で もあったことがうかがえる (Chisholm and Koike, 1996). 江戸時代人のもう一つの謎は, 上流階級の人の $\delta^{15} \mathrm{~N}$ 值 が高く，しかも陸上起源の食物を採取していたことであ る(小池ほか, 1990)。肉食が回避されたと思われるの で, 毎日海産物で蛋白源を得ていた鶏の卵を食べたか, あるいは水田肥料にイワシなどを投入した上等な白米を 食べていたのかもしれない. それで江戸時代の水田土壤 を測ろうとも考えたが，肥料になるような可給態窒素は 水溶性で残存しにくいことがわかり, 謎はまだ解けてい ない.

これからぜひ明らかにしてほしいテーマとしで飢 餓”の研究がある.これには毛髪などを用いて連続測定 することが必要で, 充分な食物が得られなくなると, 自 分の体のたんぱく質などを栄養源に用いるようになり,
栄養段階が 1 段階上がるのである．海外では拒食症患 者の回復状況に毛髪の $\delta^{13} \mathrm{C} \cdot \delta^{15} \mathrm{~N}$ が用いられている (Neuberger et al., 2013). 現生ツキノワグマの頭髪を用 いた研究では, $\delta^{13} \mathrm{C}$ と $\delta^{15} \mathrm{~N}$ の変動から飢餓状態が推定 された(安河内ほか，2008).フィリピンのミイラから採 取された頭髪でも，一部の個体に飢餓と推測されるよう な窒素同位体の変動がみられた (Garong et al., 2010).

最近，アミノ酸分析による栄養段階の推定 Amino Acid Trophic Level (ATL) 推定法という新しい方法 が海洋研究開発機構の大河内直彦氏のグループによって 開発されている(大河内ほか, 2011).この方法にはいま までのコラーゲン法より多くの試料重量を必要とする が, アミノ酸分画をしてグルタミン酸とフェニルアラニ ンの $\delta^{15} \mathrm{~N}$ を比較することによって, 直接 $\Delta \mathrm{T}$ (栄養段階 の差) が算定でき, ヒトの食性分析にも有望な手法とし て注目されている。

\section{4. その他の分析}

人は恒温動物なので ${ }^{18} \mathrm{O}$ は直接外部温度を反映する ものではなく, 飲み水の值を反映している. その飲み水の $\delta^{18} \mathrm{O}$ は扮㧍よそ緯度に沿って変化し, また雨水のように 一端水が蒸散してまた降下すると同位体分別を起こし, 高山帯では軽くなる. 分析対象はエナメル質などの結晶 質中の $\mathrm{CO}_{3}$ 中の $\delta^{18} \mathrm{O}$ を質量分析器で測定する. Ame Garong さんのフィリピン人骨の例 (Garong, 2013) で は, 各地の遺跡の平均值はほぼ緯度に沿って変化した が, Batanes 諸島の出土人骨はやや離れた值で, 雨水 を䧶に保管して飲み水を確保する習慣がその時代から行 われていたことを示唆した.

最近では ICP 質量分析計を用いて人骨の歯の ${ }^{87} \mathrm{Sr} /{ }^{86} \mathrm{Sr}$ を測定し，ヒトの移住状況などを推定している（日下， 2014). 地球化学的手法は格段の進歩を遂げており, Sr 同位体分析のように行動圈・移住・婚姻形態など社会組 織に関する知見がダイナミックに展開されることを期待 したい.

\section{5. 土器に残されたコクゾウムシ}

コクゾウムシ (款象虫, Sitophilus) 属には, いくつか の種が知られている. 縄文時代の土器圧痕のゾウムシ (山崎, 2007) を同定した森本 桂先生は九州大学箱崎 キャンパスで同室なのでいろいろ括を詞う機会に恵ま れ，その専門家としての見解をご紹介したい. 日本に生 息するのはコクゾウムシ Sitophilus zeamais とココク ゾウムシ S. oryzea だが, コクゾウムシ類の分類学的研 究は欧米で進んだため, 英名は前者が maize weevil ま たは great rice weevil, 後者が rice weevil と呼ばれて 
いる．今日日常的に米櫃などで観察されるのは，土器圧 痕から同定されたものと同じく大半がコクゾウムシで, 種々のイネ科種子 (トウモロコシ・キビ類, 小麦・大麦, イネなど）の害虫だという．コクゾウムシとココクゾウ ムシの違いはサイズのほか, 前者は野外でも飛翔して繁 殖できるが，後者は南方系の種で，日本では飛翔できな いため米倉など貯蔵庫でのみ繁殖する夕イプで，後者の 日本での由来は比較的新しいのではないかとのことだっ た.つまり土器圧痕のコクゾウムシは, 短絡的にコクゾ ウムシ＝米というのではなく, 野外で自然繁殖すること もできる夕イプであり，縄文時代の人の食料となった 種々のイネ科種子や，あるいは堅果類の実でも皮むき処 理されたものには入り込み繁殖することができ，縄文時 代の人にとっても身近な食料害虫であったと考えられ る(森本，1993)。また, 三内丸山遺跡からは新種と思わ れるコクゾウムシより大型の個体も確認されているとい う(森本私信).

\section{V. 古代 D N A}

古代 DNA（Ancient DNA；aDNA）は，遺跡出土の 動物骨の正確な同定ばかりでなく，人骨の出自，各地の 古代人の移住や系統関係を知る手段として急速に発展し ている分野の一つである.

埼玉県浦和市の円正寺人骨の発見当時は古代 DNAの 分析がやっと試みられた時代で，ミイラが人類最初の古 代DNAの例で骨からは無理だと言われていた. 1989年, 円正寺人骨は世界でも初めて骨から DNA が抽出された もののひとつになった (Horai et al., 1989). 円正寺人骨 は, 典型的な縄文人女性の特徵をもち(馬場, 1990), 人骨 の AMS 年代 (NU925: 5,830 $\pm 120 \mathrm{yBP}$ ) (中村, 1990), 食性 $\left(\delta^{13} \mathrm{C}=-20.62, \delta^{15} \mathrm{~N}=+15.0\right)$ (小池, 1990b)， そ して出自 (Horai et al., 1991) という人に関する 4つの 要素について学際的研究が行われたよい例であろう。

ヒトの DNA 解析は，出土した時点からさまざまな現 代人 DNA (片) からのコンタミにさらされる，人骨の 場合には人骨を露出することなく周りを梱包して取りあ げ，実験室内のクリーンな環境で解体しながら人骨を取 り出し，分析試料とすることが望ましい

遺跡出土の人骨から DNA を抽出しようとすると，ヒ ト用プライマーで増幅させても，たとえ極微量でも現代 人の DNA のほうが新鮮なので容易に増幅され，コンタ ミの原因となる。そこで, 動物骨の古代 DNA 研究から 始めた．動物骨の研究は野生生物の本来の遺伝的多様性 だけでなく，その動物の生態情報から古代人の行動範囲
を示したり，特定の動物，たとえば付加価值の高い動物 などを対象とした場合には民族学的意義も生じてくる. 野生動物の古代 DNA は対象動物種の行動圈からヒト の捕獲法などが推定される。アホウドリは 19 世紀から 20 世紀にかけての乱獲によって個体数を急速に減らし, 鳥島が火山噴火した時には絶滅したとも考えられたが, 今は保護され，鳥島と尖閣諸島に 2,500 羽以上生息して いる. 遺伝的には, この 2 つ島の個体は 2 群に分かれ, 古代 DNA の分析でもやはり 2 群からなり, より多様性 が豊富であった（Eda et al., 2006, 2012, 2016)。また, 遺跡で出土した鳥骨には繁殖期のものが含まれないこと から，沿岸までエサ取りに訪れた個体を捕獲したものと 推定された.

アリューシャンのアダック島出土のラッコの例 (Nishida et al., 2012) では, 未知のミトコンドリア DNA (mtDNA) のタイプが検出された．マダガスカル島にかつて生息し ていた象鳥エピオルニスはモアやキウイとおなじ走鳥類 の仲間である．近世まで生息の記録があり，ヒトの進入 によって急速に絶滅したとされる. 合同現地調査 (三原・ 小池，2014）では地質学的包含層のほかに考古遺跡から 土器片と同時に卵殼も確認された (Tovondrafale et al., 2015)。 DNA 分析により 2 属あることが確認され，系 統的にはシギダチョウに近いことが示された (Nishida et al., 2009).

次世代シークエンサーでは，全抽出 DNA をクローニ ングしすべてを読むことができ，雑菌などの混入 DNA があっても，そのデー夕の中から対象配列に近似した 断片の情報だけを選別し，それらの DNA 断片配列を 慗ぎ合わせてより長い配列として解析することができ る. 前出のエピオルニスでもこの次世代シークエンサー による分析が国立極地研で試みられ，より精度の高い系 統樹が描かれた（Yonezawa et al., 2017）.

将来はすべての人骨の DNA データベースができるこ とが期待され，民族の移動・拡散の歴史が詳細に再現さ れる日も近いかもしれない，ただし，多型解析でよく用 いられる mtDNA のコントロール領域などは重複配列 をもつ種も多く，ショットガン法や古代 DNA など短い 配列から配列デー夕を構築する際に無視されることがあ る点には注意を要する。

こう書いてみると著者個人の研究は随分順調に進んだ ように見えるが，古代 DNA の研究は肉眼では同定の困 難な骨片からでも DNA 配列が得られれば正確な同定が できると期待され始めてみたものの，堆積層中に長年置 かれていた骨から抽出された total DNA には細菌や微 
生物の DNA も多く混入していた. ヤマトシジミの殼皮 やクジラの骨なども試みたが, 雑菌が多く当時の手法で は対象 DNA 鎖をうまく増幅することはできなかった. DNA 解析では, 現生クジラ類からヘルペスウィルスが 検出されたのに気を良くして, 人骨の梅毒菌 (スピロ ヘータ）の検出を試みたが，骨学的には梅毒特有の骨変 形の症状を示しても DNA は検出できなかった.

成功して論文になる研究は $1 / 2$ か $1 / 3$ くらいかもし れない.また研究補助金の報告書を書いてしまうと一安 心して，学術論文化するのを随分总ってきた，最近の人 達は競争が激しく, 論文にしなければ話にならないし, 研究費の獲得も大変なようだ. 一昔前に学術的な人生を 卒業して助かったと思うこの頃である.

謝辞 主に筆者の人類学・考古学における研究活動を 振り返ってみた，あまり苦労せず，今振り返ってみると 懷かしい. 大学院時代は集団指導体制といって人類学教 室の教官全員が筆者の修論の指導をしてくださった。 ま た, 地質古生物・地理や大学博物館の方々も快くご相談 に乗ってくださり, 教室の先輩方や院生ともよく議論を した. これらの方々のご尽力があってこそ, 現在に至る まで研究生活を続ける基礎ができたと思っている. また, 埼玉大学時代 ・九州大学時代においては, 共同研究調査 にご協力いただいた多数の方々，また熱心に調査研究に 取り組んでくれた学生諸君に心から感謝申し上げます。

\section{引用文 献}

Akazawa, A. (1972) Report of the investigation of the Kamitakatsu shell-midden site. The University Museum, The University of Tokyo, Bulletin no. 4, $167 \mathrm{p}$.

馬場悠男（1990）浦和市円正寺出土の人骨について. 浦和市立郷土博物館研究調查報告書, 17, 1-4.

千葉県文化財センター（1976）千葉市荒屋敷貝塚：具 塚外縁部遺構確認調查報告. $103 \mathrm{p}$, 千葉県文化財セ ンター.

千葉市教育委員会編（1991）千葉市神門遺跡: 縄文時代 早・前期を主とした低湿地遺跡の調査. $311 \mathrm{p}$, 千葉 市教育委員会.

鎮西清高 - 小池裕子 - 大場忠道 - 北里 洋 - 松島義章 （1980）貝塚産貝殼の酸素同位体組成の時代的変遷と 先史時代の古環境. 文部省科学研究費特定研究「古文 化財」総括班編「自然科学の手法による遺跡・古文化 財等の研究」: 103-117, 文部省科学研究費特定研究
「古文化財」総括班.

Chinzei, K., Koike, H., Ohba, T., Kitazato, H. and Matsushima, Y. (1987) Secular changes in the oxygen isotope ratios of molluscs shells during the Holocene of the central Japan. Paleogeography, Palaeoclimatology, Paleoecology, 61, 155-166.

Chisholm, B. and Koike, H. (1996) Reconstructing prehistoric Japanese diet using stable isotopic analysis. International Research Center for Japanese Studies (ed.) Interdisciplinary perspectives on the origins of the Japanese : 199-222, International Research Center for Japanese Studies.

Chisholm, B., Nelson, D.E. and Schwarcz, H.P. (1982) Stable carbon isotope ratios as a measure of marine versus terrestrial protein in ancient diets. Science, 216, 1131-1132.

Chisholm, B. - 小池裕子・中井信之（1988）炭素安定同 位体比法による古代食性の研究. 考古学と自然科学, 20, 7-16.

Chisholm, B., Koike, H. and Nakai, N. (1993) Carbon isotope determination of paleodiet in Japan : Marine versus terrestrial sources. Aikens, C.M. and Rhee, S.N. (eds.) Pacific northwest Asia in prehistory : Recent research into the emergence of hunterfisher-gatherers, farmers and sociopolitical elites : 69-73, University of Washington Press.

DeNiro, M.J. and Epstein, S. (1981) Influence of diet on the distribution of nitrogen isotopes in animals. Geochimica Cosmochimica Acta, 45, 341-351.

Eda, M., Baba, Y., Koike, H. and Higuchi, H. (2006) Do temporal size differences influence species identification of archaeological albatross remains when using modern reference samples ? Journal of Archaeological Science, 33, 349-359.

Eda, M., Koike, H., Kuroo, M., Mihara, S., Hasegawa, H. and Higuchi, H. (2012) Inferring the ancient population structure of the vulnerable albatross Phoebastria albatrus, combining ancient DNA, stable isotope, and morphometric analyses of archaeological samples. Conservation Genetics, 13, 143-151.

Eda, M., Koike, H. and Higuchi, H. (2016) Understanding prehistoric maritime adaptations in northern Japan : Indirect evidence from ancient 
DNA and histological observations of albatross (Aves : Diomedeidae) bones. Quaternary International, 419, 159-164.

Evans, J.W. (1972) Tidal growth increments in the cockle Clinocardium nuttalli. Science, 176, 416-417.

Garong, M. (2013) Diet reconstruction using carbon, nitrogen and oxygen stable isotopes of Filipino human remains. $154 \mathrm{p}$, University of Philippine Press.

Garong, A., Mihara, S., Datar, F., Ronqullio, W. and Koike, H. (2010) Carbon and Nitrogen stable isotope analysis using human bones and hair from Philippine burial sites. Bulletin of the Graduate School of Social and Cultural Studies, Kyushu University, 16, 25-44.

本荘市教育委員会（1985）菖蒲崎貝塚調查概報一低湿 地性貝塚の調査法の開発と古環境復元に関する予報. 本荘市教育委員会編「遺跡詳細分布調査報告書」: 15-33, 本荘市教育委員会.

Horai, S., Hayasaka, K., Murayama, K., Wate, N.N., Koike,H. and Nakai,N. (1989) DNA amplification from ancient human skeletal remains and thier sequence analysis. Proceedings of Japan Academy, 65, Ser. B, 229-233.

Horai, S., Kondo, R., Murayama, K., Hayashi, S., Koike, H. and Nakai, N. (1991) Phylogenetic affiliation of anciant and contemporary humans inferred from mitochondrial DNA. Philosophical Transactions of the Royal Society of London B, 333, 409-417.

堀部純男・大場忠道 $(1977){ }^{18} \mathrm{O}-{ }^{16} \mathrm{O}$ 法による古海水温度 測定の基礎的研究一アラレ石温度スケールの検証一. 考古学と自然科学, 10, 11-19.

Ishibashi, H., Takeuchi, T., Whyte, I. and Koike, H. (1999) $\delta^{15} \mathrm{~N}$ and $\delta^{13} \mathrm{C}$ measurements from the African elephant, Loxodonta Africana used for ivory sourcing. Bulletin of the Graduate School of Social and Cultural Studies, Kyushu University, 5, 1-8. 小林正史 (2008) スス・コゲからみた土器使用法. 小杉 康, 谷口康浩, 西田泰民, 水ノ江和同, 矢野健一編 「縄文時代の考古学 7」: 143-156, 同成社.

小池裕子（1972）縄文時代上高津貝塚における貝類採 集活動と生態環境. 人類学雑誌, $80,71-72$.

Koike, H. (1973a) Daily growth lines of the clam
Meretrix lusoria -A basic study for the estimation of prehistoric seasonal gathering. Journal of Anthropological Society of Nippon, 81, 122-138.

Koike, H. (1973b) The use of daily and annual growth lines of the clam Meretrix lusoria in estimating seasons of Jomon period shell gathering. Quaternary Study, The Royal Society of New Zealand Bulletin, 13, 189-193.

Koike, H. (1979) Seasonal dating and the valvepairing technique in shell-midden analysis. Journal of Archaeological Science, 6, 63-74.

小池裕子（1979）関東地方の貝塚遺跡における貝類採 取の季節性と貝層の堆積速度. 第四紀研究, 17, 267278.

小池裕子（1981）伊血子貝塚における貝類採取の季節 性. 伊血子貝塚遺跡調查会編「伊血子貝塚遺跡」: 607-615, 東京都港区教育委員会.

小池裕子（1983a）西広貝塚における季節推定法に基づ く貝塚調查法の試み。市原市教育委員会編「西広貝塚 第 4 次」: 81-83, 国分寺台遺跡調查団.

小池裕子 (1983b) 貝類分析.「縄文文化の研究 2（生 業) 」: 221-237, 雄山閣.

小池裕子 (1983c) 縄文住居址床面の硬度分布一はけう え遺跡第 $6 \mathrm{a}$ 号住居址床面の土壤硬度測定について一. 「はけうえ遺跡・研究編 I $」: 80-87$, 国際基督教大学 考古学研究センター.

Koike, H. (1983) Measurement of soil hardness of floor surface for a reconstruction of activity patterns in a prehistoric dwelling. Asian Perspectives, XXVII, 5-13.

小池裕子（1985）貝塚調查法に関する東釧路貝塚調查 概報. 釧路市立博物館紀要, 10, 1-6.

小池裕子 (1986) 古河市黒浜期貝塚群の貝類分析. 古河 市史編纂会編「古河市史 原始・古代編」：180-194, 茨城県古河市.

Koike, H. (1986a) Microstructure of growth increments in the shell of Mercenaria mercenaria (LINNE). Transition and Proceedings of the Palaeontological Society of Japan, new series, no. 141, 289-295.

Koike, H. (1986b) Prehistoric hunting pressure and paleobiomass: An environmental reconstruction and archaeozoologicical analysis of a Jomon shellmound area. Akazawa, T. and Aikens, C.M. 
(eds.) Prehistoric hunter-gatherers in Japan, The University Museum, The University of Tokyo, Bulletin, no. $27: 27-53$, University of Tokyo Press. 小池裕子 (1987a) 貝殼成長線と古代人の生活カレン ダー. 日本古生物学会編「化石の科学」: 124-125, 朝倉書店.

小池裕子（1987b）旧目久尻川第 1 地点川床出土縄文後 期土器の脂肪酸分析. 「宮久保遺跡 I : 神奈川県立埋 蔵文化財センター調查報告書 第 15 集」:283-286, 神奈川県埋蔵文化財センター。

小池裕子 (1990a) 霬石と GC-MS. CACS FORUM 10, 28-30.

小池裕子（1990b）浦和円正寺人骨中のコラーゲンを用 いた炭素・窒素安定同位体比測定による食性分析. 浦 和市立郷土博物館研究調查報告書, 17, 5-6.

小池裕子（1991a）有用植物のステロール組成について. 埼玉大学紀要 (自然科学編), 26, 13-29.

小池裕子 (1991b) 大分県安岐町久末京徳遺跡出土の螜 型土器内土猿の脂質分析について. 大分県教育委員会 編「久末京德遺跡」: 67-70, 大分県教育委員会.

小池裕子（1992a）生業動態からみた先史時代のニホン ジカ狩猟について. 国立歴史民俗博物館研究報告, 42, $15-45$.

小池裕子（1992b）安定同位体からみた日本人の食性変 化一縄文時代から江戸時代まで一，名古屋大学年代測 定資料研究センターシンポジウム論文集「加速器質量 分析と炭素安定同位体の学際的応用」, 91-97.

小池裕子 (1992c) 土器付着物の $\delta^{13} \mathrm{C}$ 測定にもとづく食 性分析について. 石川県立埋蔵文化財センター年報, 12, 153-158.

Koike, H. (1992) Exploitation dynamics during the Jomon period. Aikens, C.M. and Rhee, S.N. (eds.) Pacific northwest Asia in prehistory : Recent research into the emergence of hunter-fishergatherers, farmers and sociopolitical elites : 53-56, University of Washington Press.

小池裕子（1995）安定同位体を指標としたマングロー ブ林生物の栄養段階と物質循環に関する研究.「熱帯 アジア地域に扔ける湿地の生物多様性保全に関する研 究」:214-226, (財) 自然環境研究センター.

小池裕子 (1999) 千葉県下出土人骨の炭素・窒素安定 同位体測定. 千葉県埋蔵文化財センター研究紀要, 19, 54-58.

小池裕子（2000）食料資源県境と人類.「環境と人類」：
31-60, 朝倉書店.

Koike, H. and Chisholm, B. (1991) Paleodiet of huntergatherers in Japan estimated by ${ }^{13} \mathrm{C}^{-15} \mathrm{~N}$ and lipid analysis. The Quaternary Research (Daiyonkikenkyu), 30, 231-238.

小池裕子・林 良博 (1984) 遺跡出土ニホンイノシシ の齢查定について．古文化財に関する保存科学と人 文・自然科学一総括報告書一, 519-524.

小池裕子・中島 徹 $(1988){ }^{13} \mathrm{C}$ 法を用いた小櫃川河口 干潟の食物網構造について. 日本ベントス研究会誌, $33 \cdot 34,15$.

小池裕子 - 中島 徹 (1989) 安定同位体と消化管珪藻分 析による干潟食物網の解析について一現生生態学と古 生態学の接点一. 日本ベントス研究会誌, 37, 1-10.

Koike, H. and Nakano, M. (1987) Lipid analysis for prehistoric diet composition. Journal of the Anthropological Society of Nippon, 95, 257.

小池裕子・大泰司紀之 (1984) ニホンシカの齢構成か らみた狩猟圧の時代変化. 古文化財に関する保存科学 と人文・自然科学一総括報告書一, 508-517.

Koike, H. and Ohtaishi, N. (1985) Prehistoric hunting pressure estimated by the age composition of excavates sika deer (Cervus nippon) using the annual layer of tooth cement. Journal of Archaeological Science, 12, 443-456,

Koike, H. and Ohtaishi, N. (1987) Estimation of Prehistoric Hunting Rates based on the Age Composition of Sika Deer (Cervus nippon). Journal of Archaeological Science, 14, 251-269.

Koike, H. and Okamura, M. (1994) Time-scaling of successively accumulated shell layers for exploitation dairy analysis. ArchaeoZoologia, VI-2, 23-36.

小池裕子 - 土屋朋子 (1988) 水産動物の脂肪酸組成に ついて. 埼玉大学紀要 (自然科学編), 24, 55-72.

小池裕子 - 左古直美 - 佐藤里恵 (1990) 都立上野高等 学校遺跡の上野寛永寺護国院墓地から出土した人骨の $\delta^{13} \mathrm{C} \cdot \delta^{15} \mathrm{~N}$ 測定による食性分析. 都立上野高等学校遺 跡発掘報告書, 369-374, 都立学校遺跡調査会.

小池裕子 - Chisholm, B. 岩崎純子 (1992a) 古人骨の $\delta^{13} \mathrm{C}$ 測定值 (1). 九州大学解剖学教室保管標本を中 心とした西南日本古人骨の $\delta^{13} \mathrm{C}$ 值. 埼玉大学紀要 (自 然科学編), 27, 19-31.

小池裕子 - Chisholm, B. 坂詰久美子 (1992b) 古人骨 の $\delta^{13} \mathrm{C}$ 測定值 (2) 一札幌医科大学解剖学教室保管標 
本を中心とした北海道古人骨の $\delta^{13} \mathrm{C}$ 值. 埼玉大学紀 要 (自然科学編), 27, 33-44.

小杉正人（1985）染色像による珪藻の生体・遺骸の識 別法とその意義. 第四紀研究, 24, 139-147.

小杉正人・金山喜昭・張替いづみ・樋泉岳二 · 小池裕子 （1989）古奥東京湾周辺における縄文時代黒浜期の貝 塚形成と古環境. 考古学と自然科学, 21, 1-22.

日下宗一郎 (2014) 自然人類学における同位体分析の 応用一縄文人の食性と移動一. 海洋化学研究, 27 , 50-54.

Leiss-Holzingor, E., Wiesauer, K., Stephani, H., Heise, B., Stifter, D., Kriechbaumer, B., Spachinger, S.J., Gusenbauer, C. and Withalm, G. (2015) Imaging of the inner structure of cave bear teeth by novel non-destructive techniques. Palaeontologia Electronica, 18 (1), 1T, 1-15.

Luts, R.A. and Rhoads, D.C. (1977) Anaerobiosis and a theory of growth line formation. Science, 198, 1222-1227.

松井 功 - 小池裕子 - 小野 昭 (1991) 豊原遺跡出土 シカ遺体の狩猟季節について. 巻町町史研究, VII, 1-9.

松島義章 (2012) 貝が語る縄文海進一南関東, $+2^{\circ} \mathrm{C}$ の 世界. $232 \mathrm{p}$, 有隣堂.

三原正三・小池裕子 (2014) マダガスカルのエピオル ニス調査一長岡氏による砂丘編年を中心に一. 月刊地 球, 36, 233-239.

Mihara, S., Miyamoto, K., Nakamura, T. and Koike, H. (2004a) ${ }^{14} \mathrm{C}$ chronology for human bones during the Yayoi period -the calibration ambiguity for ${ }^{14} \mathrm{C}$ ages around $2400 \mathrm{BP}$ and the marine reservoir effect-. Nuclear Instruments and Methods in Physics Research B, 223-224, 700-704.

Mihara, S., Miyamoto, K., Ogawa, H., Kurosaki, T., Nakamura, T. and Koike, H. (2004b) AMS ${ }^{14} \mathrm{C}$ dating using black pottery and fiber pottery. Radiocarbon, 46, 407-412.

Mihara, S., Fengshi, L., Koike, H. and Miyamoto, K. (2007) The stable isotope analysis of carbon from the black potteries of Longshan culture in Haidai region. Eastern Archaeology, 3, 299-305.

Minagawa, M. and Wada, E. (1984) Stepwise enrichrnent of ${ }^{15} \mathrm{~N}$ along foodchains : further evidence and the relation between $\delta^{15} \mathrm{~N}$ and animal age. Geochimica Cosmochimica Acta, 48, 11351140.

Mitani, N., Mihara, S., Ishii, N. and Koike, H. (2006) Natural distribution of ${ }^{13} \mathrm{C}$ and ${ }^{15} \mathrm{~N}$ values of flora and fauna in Tsushima. Bulletin of the Graduate School of Social and Cultural Studies, Kyushu University, 12, 25-38.

Mitani, N., Mihara, S., Ishii, N. and Koike, H. (2009) Clues to the cause of the Tsushima leopard cat (Prionailurus bengalensis euptilura) decline from isotopic measurements in three species of carnivora. Ecological Research, 24, 897-908.

森本 桂（1993）原色ペストコントロール困説 第 IV 集. $52 \mathrm{p}$, 日本ペストコントロール協会.

内藤靖彦・小池裕子 (1984) 北海道オホーツク期オン ネモト・トコロチャシ遺跡出土アザラシ類の齢査定に ついて. 古文化財に関する保存科学と人文・自然科学 一総括報告書一, 529-531.

中村俊夫 (1990) 名古屋大学タンデトロン加速器質量 分析計による放射性炭素年代測定結果報告. 浦和市立 郷土博物館研究調查報告書, $17,7-8$.

Neuberger, F.M., Jopp, E., Graw, M., Puschel, K. and Grupe, G. (2013) Signs of malnutrition and starvation-Reconstruction of nutritional life histories by serial isotopic analyses of hair. Forensic Science International, 226, 22-32.

日本第四紀学会編（1987）日本第四紀地図. $119 \mathrm{p}$, 東 京大学出版会.

Nishida, S., Yonezawa, T., Hasegawa, M., Mukoyama, H., Yoshida, K., Nagaoka, S., Rasoamiaramanana, A.H., Koike, H., Yoshida, A. and Akishinonomiya, F. (2009) Ancient DNA analysis of the extinct elephant birds (Aepyornithidae) in Madagascar. Proceedings of International Darwin Bicentennial Symposium at Sapporo, S1-2.

Nishida, S., West, D., Crockford, S. and Koike, H. (2012) Ancient DNA analysis for the sea otter (Enhydra lutris) from archaeological sites on Adak, Aleutian Islands. West, S. and Crockford, D. (eds.) The people before: The archaeology and paleobiology of Adak Island, Aleutian Islands, Alaska : 147-156, The Alaskan Anthropological Association monograph series.

大河内直彦 -内藤裕一 - 力石嘉人 - 米田 穣 $(2011)$ 
縄文人の食性：新しい方法論からの視点. 科学, 81 , 1116-1117.

Ohno, T. (1989) Paleotidal characteristics determined by micro-growth patterns in bivalves. Palaeontology, 32, 237-263.

小野 昭 - 前山精明 - 小林嚴雄 - 小池裕子 - 島村忠淳 (1988) 巻町豊原遺跡の調查. 巻町町史研究, IV, 1-71. 桜井均・小池裕子（1989）粪のステロール組成によ る食性分析について. 哺乳類科学, $29,65$.

瀬川裕一郎・小池裕子（1990）煮堅魚と鍋型土器・覚 え書. 沼津市博物館紀要, 14, 1-19.

樋泉岳二（1999）東京湾地域における完新世の海洋環 境変遷と縄文貝塚形成史. 国立歴史民俗博物館研究報 告, 81, 289-310.

Tovondrafale, T., Razakamanana, T, Koike, H. and Rasoamiaramanana, A. (2015) Paleoecological analysis of elephant bird (Aepyornithidae) remains from the Late Pleistocene and Holocene formations of southern Madagascar. Malagasy Nature, 8, 1-13.

辻 誠一郎・南木睦彦・小池裕子 (1992) 下総台地西部 における完新世後半の植物化石群と植生史. Journal of Phytogeography and Taxonomy, 40, 47-54.

Uno, H. (1962) Studies on the aquiculture of Turbo cornutus Solander with special reference to ecology and periodicity of the growth. Journal of Tokyo University of Fishery. Special Edition, 6, 1-71.

浦和市遺跡調査会 (1985) 山久保遺跡発掘調查報告書 〈第 2 次〉. 浦和市遺跡調查会報告書 第 55 集, $58 \mathrm{p}$, 浦和市遺跡調查会.

Wilbur, K.M. and Yonge, C.M. (1964) Physiology of mollusca. 1118 p, Academic Press.

山崎純男 (2007MS) 九州縄文時代生業の研究. 熊本大 学学位論文, $454 \mathrm{p}$.

安河内彦輝 - 三原正三 - 黒崎敏文 - 米田政明 - 小池裕子 （2008）2004 年秋のツキノワグマ大量出没に関する体 毛の炭素・窒素安定同位体比からみた栄養診断の試 み. 保全生態学研究, 13, 257-264.

Yonezawa, T., Segawa, T., Mori, H., Campos, P.F., Hongoh, Y., Endo, H., Akiyoshi, A., Kohno, N., Nishida, S., Wu, J., Jin, H., Adachi, J., Kishino, H., Kurokawa, K., Nogi, Y., Tanabe, H., Mukoyama, H., Yoshida, K., Rasoamiaramanana, A., Yamagishi, S., Hayashi, Y., Yoshida, A., Koike, H., Akishinonomiya, F., Willerslev, E. and Hasegawa, M. (2017) Phylogenomics and morphology of extinct paleognaths-Reveal the origin and evolution of the ratites. Current Biology, 27, 68-77. 
The Paper for the 2015 Japan Association for Quaternary Research Award

Food strategy during the Jomon Period based on exploitation dynamics: Jomon culture as a pioneer of sustainable use

\author{
Hiroko Koike*
}

This paper, as a JAQUA Award paper, introduces exploitation dynamics theory as applied to food strategy during the Jomon period. The author started shell growth-line analysis by research on shell structure and shell formation mechanism, and then conducted seasonality analysis of shell collecting activities using shells excavated from numerous shell layers at shell mound sites and dwelling sites. These researches led to the development of paleo biomass analysis derived from the reconstruction of the marine environment. In the process of seasonal dating on shellfish and other animals, the author developed exploitation dynamics and hunting-collecting pressure analyses to consider the relationship between humans and food resources, especially the sustainable use practices of the Jomon people. The underlying thought of this seems to reflect a wide range of knowledge of resource management, not only the ecology of the target animals and plants but also appropriate select on and management, such as setting upper limits on deer capture. Exploitation dynamics analysis is expected to apply to social stratification, immigration, and diffusion of settlements by applying new technologies such as ancient DNA, comparing the increase-type village with the saturation-type village of the Jomon period.

Keywords : shell growth-line analysis, tooth annuli analysis, paleo biomass analysis, exploitation dynamics, hunting-collecting pressure, exploitation diary

\footnotetext{
* University Museum, University of Kyushu. 6-10-1 Hakozaki, Higashi-ku, Fukuoka, 812-8581, Japan. E-mail : hkoike@museum.kyushu-u.ac.jp
} 